\title{
Spatial and temporal variations in trace metal concentrations in surface sediments of the Marennes Oléron Bay. Relation to hydrodynamic forcing
}

\author{
Emilie Strady $^{\mathrm{a}, *}$, Stéphane Kervella ${ }^{\mathrm{b}, * *}$, Gérard Blanc $^{\mathrm{a}}$, Serge Robert ${ }^{\mathrm{b}}$, Jean Yves Stanisière ${ }^{\mathrm{c}}$, \\ Alexandra Coynel ${ }^{\mathrm{a}}$, Jörg Schäfer ${ }^{\mathrm{a}}$ \\ a Université Bordeaux 1, UMR 5805 EPOC CNRS, GEMA Team, Avenue des Facultés, 33405 Talence, France \\ ${ }^{\mathrm{b}}$ IFREMER - LER/PC, BP 7 - Place Gaby Coll, 17137 L'HOUMEAU, France \\ ' IFREMER, Station de la Trinité-sur-mer, 12 rue des Résistants, BP 2656470 La Trinité-sur-Mer, France
}

\section{A R T I C L E I N F O}

\section{Article history:}

Received 22 July 2010

Received in revised form

23 February 2011

Accepted 16 March 2011

Available online 23 March 2011

Keywords:

Trace metal

Marennes Oléron Bay

Enrichment factor

Sediment

Hydrodynamic

Altus

\begin{abstract}
A B S T R A C T
Sediments quality assessment is of priority concern to provide a comprehensible overview of ecological and chemical state of an ecosystem. The Marennes-Oléron Bay, hosting the largest oyster production in France, is influenced by the historic polymetallic pollution of the Gironde Estuary. Despite, management efforts and decreasing emissions in the Gironde watershed, Cd levels in oysters from the bay are close to consumption limit $\left(5 \mu \mathrm{g} \mathrm{g}^{-1} \mathrm{dw}, \mathrm{EC}\right.$ no. 466/2001). In this context, the aim of the study was to assess the priority metal ( $\mathrm{Ni}, \mathrm{Cu}, \mathrm{Zn}, \mathrm{As}, \mathrm{Ag}, \mathrm{Cd}, \mathrm{Hg}, \mathrm{Pb}$ and $\mathrm{Th}$ ) concentrations in sediment within the Bay, by investigating spatial and temporal distribution variations and the role of hydrodynamic forcing. For that we selected three sites (east, west and south) characterizing different environments of the Bay and we observed metal concentrations, grain size distribution, bed elevation and wave activities during a year survey. The sampling strategy pointed out both spatial and temporal metal concentrations variability in sediment. In general, metal enrichments were close to geochemical background. The eastern part of the Bay, largely influenced by the Charente river particulate deposition, presented constant concentrations over the survey. In contrast, in the western part, bed elevation was strongly influenced by hydrodynamic forcing especially wave activities, and metal distribution showed constant metal concentrations except very located $\mathrm{Cd}$ minor enrichment related to the Gironde influence via the Antioche Strait (north). The southern part was disconnected from the rest of the Bay and showed minor to very located moderately severe $\mathrm{Cd}$ enrichment, related to the Gironde water discharges via the Maumusson Strait (south). Thus, the multi-disciplinary approach was relevant to characterize the interactions between hydrodynamic forcing on the environment and sediments and their metal quality state which (i) were close to geochemical background over a year for $\mathrm{Ni}, \mathrm{Cu}, \mathrm{Zn}, \mathrm{As}, \mathrm{Ag}, \mathrm{Hg}$ and $\mathrm{Pb}$ (i) which presented enrichment of $\mathrm{Cd}$ in the western and southern part.
\end{abstract}

(c) 2011 Elsevier Ltd. All rights reserved.

\section{Introduction}

Sediment particles have been identified as key factors in metal/ contaminants transport from the continent to the ocean and play an important role in river basin and coastal area (Förstner and Salomons, 2008). They can act as a source or a sink of metalbounded particles or dissolved metal in the interstitial water, which can significantly modify contaminant distribution, behavior and ecotoxicological impact. In coastal zone, sediments may be considered as ultimate receptacle of marine organic/inorganic suspended

\footnotetext{
* Corresponding author.

* Also corresponding author. Present address: Geotransfert, University Bordeaux1, UMR 5805 EPOC CNRS, Avenue des Facultés, 33405 Talence, France.

E-mail addresses: e.strady@epoc.u-bordeaux1.fr (E. Strady), s.kervella@epoc. u-bordeaux1.fr (S. Kervella).
}

particulate matter (SPM) and terrigenous inputs from estuarine and riverine watersheds. However, coastal tidal dynamic can induce sediments resuspension and remobilisation which affect trace metal cycle. The Water Framework Directive (Förstner and Salomons, 2008)(WFD) aims at attempting a good ecosystem health in aquatic systems (2000/60/EC). The ecological status is based upon the status of biological, hydromorphological and physico-chemical quality elements, including priority substances (2005/105/EC), as trace metals (Borja et al., 2004). Despite sediment assessment is not mentioned in the WFD monitoring, their quality assessment is of major scientific concern (Apitz and Power, 2002; Crane, 2003; Borja et al., 2004; Apitz, 2008; Tueros et al., 2009, Corbett et al., 2009; Essien et al., 2009; Valdès et al., 2009).

The Marennes-Oléron Bay (MOB, Fig. 1a) is a semi-closed bay of $156 \mathrm{~km}^{2}$, with $58 \%$ of intertidal areas and a tidal range of $5 \mathrm{~m}$ (Bassoullet et al., 2000; Gouleau et al., 2000) located between the 
a

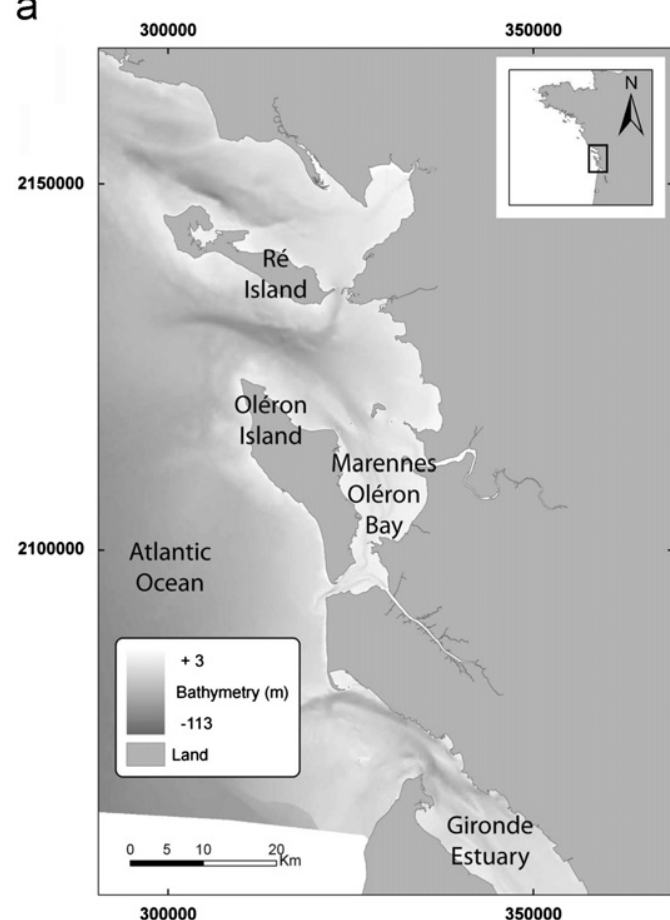

b

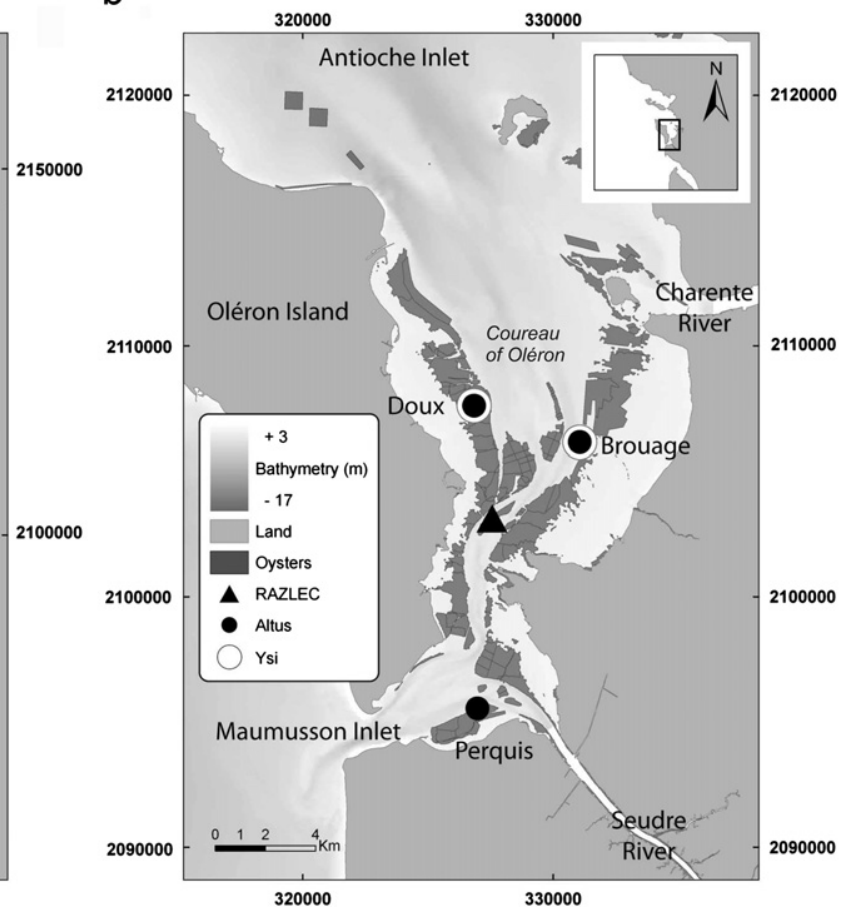

Fig. 1. (a) Localization of the Marennes Oléron Bay in south-western France, (b) zoom on the Marennes Oléron Bay and the location of three sampling sites.

Oléron Island and the Charente coast in south-western France. The Bay hosts the largest oyster production in France, as one third of its intertidal areas are covered by oyster structures several months per year (Goulletquer and Le Moine, 2002). The annual production of 55-60 $\mathrm{tyr}^{-1}$ generates important regional economy related to farming and tourisms activities. However, the MOB is influenced by the historical cadmium pollution from the Gironde Estuary (Latouche, 1988; Boutier et al., 1989, 2000; Jouanneau et al., 1990; Dabrin, 2009). The Cd is transported through the dissolved phase (Boutier et al., 2000; Dabrin, 2009) and through fine sediments and particles (Pouliquen, 1975; Castaing and Allen, 1981; Boutier et al., 1989, 2000; Froidefond et al., 1998; Parra et al., 1999; Dabrin, 2009). The pollution of the Lot-Garonne-Gironde fluvial-estuarine system originates $350 \mathrm{~km}$ upstream from former mining activities, especially ore treatment, in the Decazeville watershed (Jouanneau et al., 1990; Lapaquellerie et al., 1995; Blanc et al., 1999; Schäfer and Blanc, 2002; Audry et al., 2004b, 2010; Coynel et al., 2009). Despite management efforts and decreasing emissions in the watershed (Audry et al., 2004a; Coynel et al., 2007), dissolved and particulate $\mathrm{Cd}$ net fluxes exported from the Estuary to the coastal zone were estimated of 5100 and $800 \mathrm{~kg} \mathrm{yr}^{-1}$, respectively (Dabrin, 2009; Dabrin et al., 2009). From the 1980s, the French National Monitoring Network (Réseau National Observation, RNO), under the IFREMER responsibility, bio-monitored $\mathrm{Cd}$ contamination in oysters collected in the Gironde Estuary and the MOB (RNO, $2000,2006)$. The Cd contents in oysters from the Gironde Estuary (RNO, 2000, 2006) were significantly higher than the consumption limit level ( $5 \mu \mathrm{g} \mathrm{g}^{-1} \mathrm{dw}$, EC no.466/2001) conducting to the interdiction of oysters' production, selling and consumption in the Estuary. The Cd concentrations in oysters from the MOB are below but still close to this consumption limit level (RNO, 2000, 2006). Assessment of sediment quality in the MOB is thus of priority concern to implement a successful ecosystem management.

This study aims at assessing sediment metal quality by evaluating trace metal (e.g. $\mathrm{Ni}, \mathrm{Cu}, \mathrm{Zn}, \mathrm{As}, \mathrm{Cd}, \mathrm{Hg}, \mathrm{Pb}$, more $\mathrm{Th}$ ) in surface sediments. In such environment characterized by strong tidal variations, sedimentary processes as erosion and accretion are temporally highly dynamic. It is thus essential to determine if those sedimentary variations are accompanied by or affecting trace metal concentrations in sediments. For that, we proposed and discussed an original sampling strategy combining both geochemical and hydrodynamical survey to understand and integrate hydrologic and hydrodynamic forcing over spatial and temporal scale. Thus in the same time, spatial and temporal sediment variability, bed elevation and hydrodynamic forcing were monitored at three sites over a year in order to discuss the influence of sedimentary and hydrodynamic forcing on sediment metal quality of the Marennes Oléron Bay.

\section{Material and methods}

\subsection{Study area}

The Marennes Oléron Bay (MOB; Fig. 1b) is a shallow macrotidal bay, with an $8.6 \mathrm{~m}$ depth average and a tidal range of $5 \mathrm{~m}$. It receives the fresh waters of Charente River in the North (with a $40-470 \mathrm{~m}^{3} \mathrm{~s}^{-1}$ flow), (Soletchnik et al., 1998) and the ones of Seudre River in the South (with a $0-40 \mathrm{~m}^{3} \mathrm{~s}^{-1}$ flow, according to the same authors). It can be divided into three sediment areas (Tesson, 1973; Pouliquen, 1975). The north-eastern Bay is a $40 \mathrm{~km}^{2}$ large mudflat composed of $92 \%$ clay and silt particles (Gouleau et al., 2000; Galois et al., 2000), from Charente River, Seudre River and salt marshes, which locally presented specific drainage systems called "ridges and runnels". The western Bay is a marine mixed sandy and muddy flat, of which sediments are partly originated form the Gironde Estuary (Hily, 1977; Sauriau et al., 1989) and characterized by shellfish farming installations in the lower part and seasonal presence of seagrass zoostera noltii in the upper part (Guillaumont, 1991). The central to southern Bay, from "Coureau of Oléron" to Maumusson Strait, is compound of calcareous and siliceous sandy sediments coming from coastal limestone cliffs and dune under littoral drift action. It is 
characterized by important permanent oysters farming activities, inducing sandbars and silt deposition (Kusuki, 1978; Sornin, 1981; Martin et al., 1989; Kervella, 2010).

Currents circulation: the particular bathymetry and the difference of size between the two openings, the Antioche Strait (North) and the Maumusson Strait (South) (Fig. 1) bring a residual water circulation oriented along a north-south axis, with assymmetric ebb and flood tides (Klingebiel et al., 1971; Bertin et al., 2005; Stanisière et al., 2006). During calm weather period, marine waters penetrate by the Antioche Strait and the Charente waters flow on the eastern side of the bay (Stanisière et al., 2006). Thus, the central part of the Bay called "Coureau of Oléron" is influenced by seawater mass (salinity $>30$ ) and less saline water mass (salinity $<30$ ) constituted by a mixing between marine waters and Charente ones (Tesson, 1973). The southern Bay is slightly influenced by the marine waters entering via the Maumusson Strait because of the higher ebb tidal prism (Bertin et al., 2005; Stanisière et al., 2006). Thus, the water residence time was estimated of 4-11 days in the western part, 7-16 days in the eastern part and 0.5-5 days in the south of the Bay (Struski, 2005). The current maxima $\left(1 \mathrm{~m} \mathrm{~s}^{-1}\right)$ are observed during spring tides in subtidal areas (Tesson, 1973) whereas currents do not exceed $0.60 \mathrm{~m} \mathrm{~s}^{-1}$ in intertidal areas (Bassoullet et al., 2000).

Wave activity: wave propagation in the bay comes roughly from the Antioche Strait. Waves are strongly attenuated in the south because of the narrowness of the Maumusson Strait and the singular bathymetry in this area. In the MOB, waves are responsible of significant sediment transport at these openings under littoral drift action, while wind waves cause fine sediment resuspension on mudflats (Tesson, 1973; Bassoullet et al., 2000). Despite few data available, Bassoullet et al. (2000) have recorded waves of about $0.70 \mathrm{~m}$ high on the Brouage mudflat (east) using pressure sensors in stormy periods.

Field sites: three intertidal sites were selected according to the Bay environmental characteristics and were studied during a year (Fig. 1b). The first site, called "Les Doux", was located in the middle of the oyster area in the low part of the western flat. During this study, no oyster installations were present. The second site called "Brouage" was located in the low part of the eastern mudflat between the wild oyster area and the "Coureau" of Oléron. The third site called "Perquis" was located on the western part of the Perquis sand bank in the southern part of the Bay, in annual oyster installation area.

\subsection{Methodology and analysis}

\subsubsection{Sampling}

Surface sediments $(0-5 \mathrm{~mm})$ were collected monthly at each site using a plastic spatula. Sediments were immediately introduced into a $60 \mathrm{~mL}$ PE tube hermetically closed to avoid re-oxidation processes and kept refrigerated in the dark at $4{ }^{\circ} \mathrm{C}$ until particle size, water content and metal analyses.

\subsubsection{Turbidity and salinity}

Salinity and turbidity data were recorded by multi-parameters probes (Ysi) located at the Agnas bank (monitoring network RAZLEC, IFREMER) and at Les Doux and Brouage sites during 16 days (06-22 April 2007). These probes were positioned ten centimetres from the bottom and temperature and salinity were recorded once every $10 \mathrm{~min}$.

\subsubsection{Sedimentary parameters}

Grain size analyses were performed using Beckman Colter laser diffraction (LS13 320; focal $780 \mathrm{~nm}$; from 0.4 to $2000 \mu \mathrm{m}$ ). The upper limit of clay was fixed at $2 \mu \mathrm{m}$ and the limit between silt and sand to $50 \mu \mathrm{m}$ according to USDA standard. Each analysis was performed with seawater to avoid deflocculation processes and take into account environmental physico-chemical characteristics (Pantet et al., 2010). Before analyses, a blank was realised to eliminate micro organisms and salt contents. The water content ( $W$, in \%) was defined as (Kervella et al., 2009)

$$
\begin{aligned}
& W=\frac{M_{w}}{M_{d}} \text { with } M_{w} \text { : wet mass }(g) \text { and } \\
& \qquad M_{d}: \operatorname{dry} \operatorname{mass}(g) \text { after } 72 \mathrm{~h} \text { drying at } 55^{\circ} \mathrm{C}
\end{aligned}
$$

\subsubsection{Bed-elevation and wave measurements}

Bed level variations, related to waves and tide currents, were continuously recorded at each site from April 2007 to April 2008 using altimeter devices (ALTUS; NKE ${ }^{\circledR}$ ). The ALTUS system is an echo-sounder recording bed elevation and water height with an accuracy of 0.2 and $20 \mathrm{~mm}$, respectively (Jestin et al., 1998). During this study, wave and bed parameters were recorded during $300 \mathrm{~s}$ every $20 \mathrm{~min}$ at a frequency of $2 \mathrm{~Hz}$. The transmitter was positioned at 25 to $40 \mathrm{~cm}$ above the bottom. The distance between transmitter and bottom is estimated on acoustic waves speed propagation in water. Therefore, a correction of the bed elevation signal is necessary, using Coppens equation, according to changes of environmental temperature and salinity (Deloffre et al., 2005). In this study, we used temperature and salinity data from the monitoring network RAZLEC (IFREMER) located at Agnas bank (middle MOB) to correct the acoustic signal. Thus, we determined the significant wave height $H_{\text {sig }}$ from water level measurement, according to the following equation:

$H_{\text {sig }}=4 \sqrt{m_{0}}=4 \sqrt{\int S_{p}(f) d f} \cong \sqrt{\sum S_{p}\left(f_{i}\right) \Delta f_{i}}$

where $S_{p}$ is the pressure spectral density (corrected from depth attenuation), $f$ is the wave frequency and $m_{0}$ is the variance of the water surface elevation.

\subsubsection{Trace metal analysis}

For analyzing $\mathrm{Cr}, \mathrm{Ni}, \mathrm{Cu}, \mathrm{Zn}, \mathrm{As}, \mathrm{Ag}, \mathrm{Cd}, \mathrm{Pb}$ and $\mathrm{Th}$, representative sub-samples of surface sediments $(30 \mathrm{mg}$ of dried, powdered and homogenized material) were digested into acid-pre-cleaned PP-tubes (SCP sciences ${ }^{\circledR}$ ) using $1 \mathrm{~mL} \mathrm{HNO}_{3}\left(14 \mathrm{M}\right.$, suprapur $\left.{ }^{\circledR}\right), 3 \mathrm{~mL} \mathrm{HCl}(12 \mathrm{M}$, suprapur $^{\mathbb{R}}$ ) and $2.5 \mathrm{~mL} \mathrm{HF}\left(26 \mathrm{M}\right.$, suprapur ${ }^{\mathbb{R}}$ ). The reactors were heated at $110^{\circ} \mathrm{C}$ for $2 \mathrm{~h}$ using a temperature controlled digestion system DigiPrep ${ }^{\circledR}$ (SCP sciences). After cooling, the digested solution was evaporated until dryness, and the digestate was diluted to $10 \mathrm{~mL}$ using $250 \mu \mathrm{L} \mathrm{HNO}_{3}\left(14 \mathrm{M}\right.$, suprapur $\left.{ }^{\circledR}\right)$ and milli-Q water ${ }^{\circledR}$. Trace metal concentrations were measured by ICP-MS (Thermo X7), using external calibration. The analysis and measurements were quality controlled using, respectively, certified marine sediments (BCSS-1) and riverine water (SLEW-3). Recoveries and reproducibility are presented in Table 1.

For analyzing $\mathrm{Hg}$ representative sub-samples of surface sediments (70 mg of dried, powdered and homogenized material)

Table 1

\begin{tabular}{|c|c|c|c|c|c|c|c|c|c|c|}
\hline & $\mathbf{N i}$ & $\mathbf{C u}$ & Zn & As & Ag & Cd & $\mathbf{P b}$ & Th & & Hg \\
\hline $\begin{array}{l}\text { BCSS-1 } \\
\text { mg kg }^{-1}\end{array}$ & $\begin{array}{r}5.3 \pm 3.6 \\
56.5 \pm 5.5\end{array}$ & $\begin{array}{l}18.5+2.7 \\
20.0 \pm 6.1\end{array}$ & $\begin{array}{c}119+12 \\
92.6 \pm 3.5\end{array}$ & $\begin{array}{l}11.1 \pm 1.4 \\
10.4 \pm 0.6\end{array}$ & $0.18 \pm 0.00$ & $\begin{array}{r}0.25 \pm 0.04 \\
0.32 \pm \mathbf{0 . 0 1}\end{array}$ & $\begin{array}{l}22.7 \pm 3.4 \\
22.3 \pm 0.6\end{array}$ & $6.9 \pm 0.07$ & $\begin{array}{l}\text { IAEA-405 } \\
\mathrm{mg} \mathrm{kg}^{-1}\end{array}$ & $\begin{array}{l}\mathbf{0 . 8 1} \pm \mathbf{0 . 0 4} \\
\mathbf{0 . 8 0} \pm \mathbf{0 . 0 6}\end{array}$ \\
\hline
\end{tabular}

Concentrations of certified reference material, BCSS-1 and IAEA-405 for Hg. 
were measured by cold-vapor atomic spectrometry (DMA $\left.{ }^{\circledR}\right)$ and quality controlled using IAEA-405 certified sediment.

\section{Results}

\subsection{Salinity and turbidity}

Measured salinity showed net temporal and spatial variations (Fig. 2a). Three situations were pointed out: (A) salinity measured at Agnas (RAZLEC, IFREMER) and Brouage are relatively low (31.5) and followed the same tendency whereas at Les Doux salinity is slightly higher (32) and varied differently; (B) salinity measured at Les Doux was close to Agnas but lower than Brouage (10-14 February 2007), showing freshwater inputs from the Gironde
Estuary via the Antioche Strait; (C) same situation as (A) with higher salinity, showing decreasing freshwater inputs to the Bay. Turbidity (Fig. 2b) measured at Les Doux and Agnas (RAZLEC, IFREMER) in spring tides were relatively lower $\left(10-150 \mathrm{mg} \mathrm{L}^{-1}\right)$ then those measured at Brouage $\left(10-500 \mathrm{mg} \mathrm{L}^{-1}\right)$.

\subsection{Grain size distribution}

Sediment fractions and water contents varied temporally and spatially (Fig. 3). At Les Doux and Perquis sites, sediments were dominated by the marine sandy fraction throughout the year $(87 \%$ and $81 \%$, respectively) and characterized by a mean median grain size distribution of 209 and $194 \mu \mathrm{m}$, respectively. However, a slight increase in fine fraction (silt+clay, 26\%) was observed during the summer. In those two sites, the water content was low (40\% and $43 \%$,

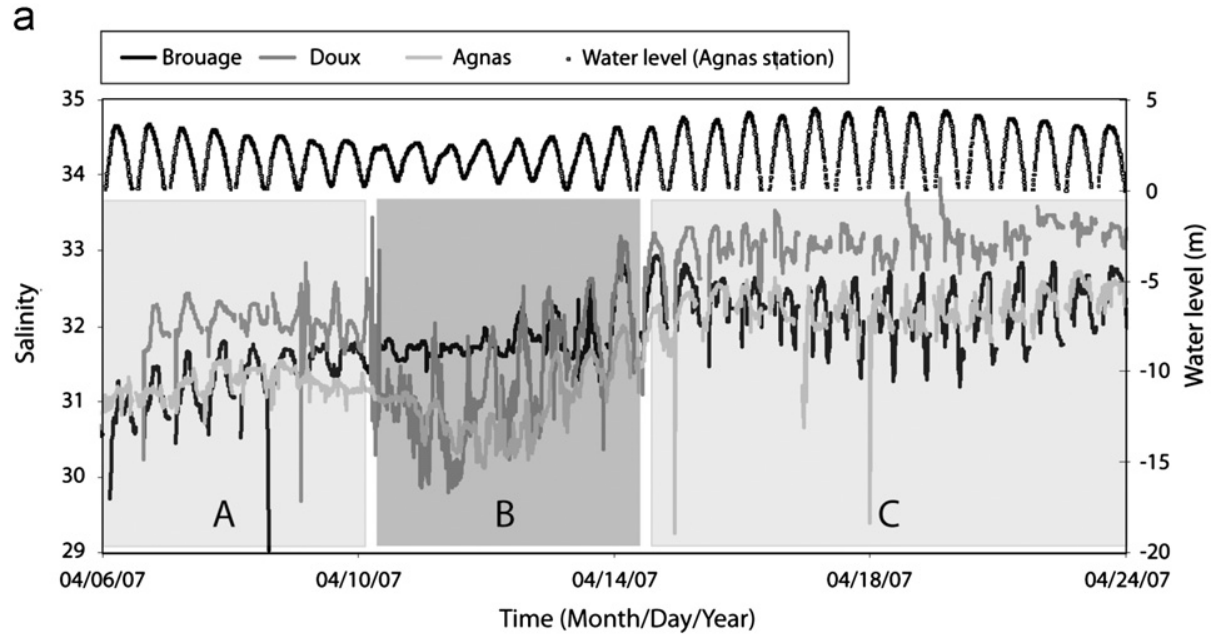

$\mathrm{b}$

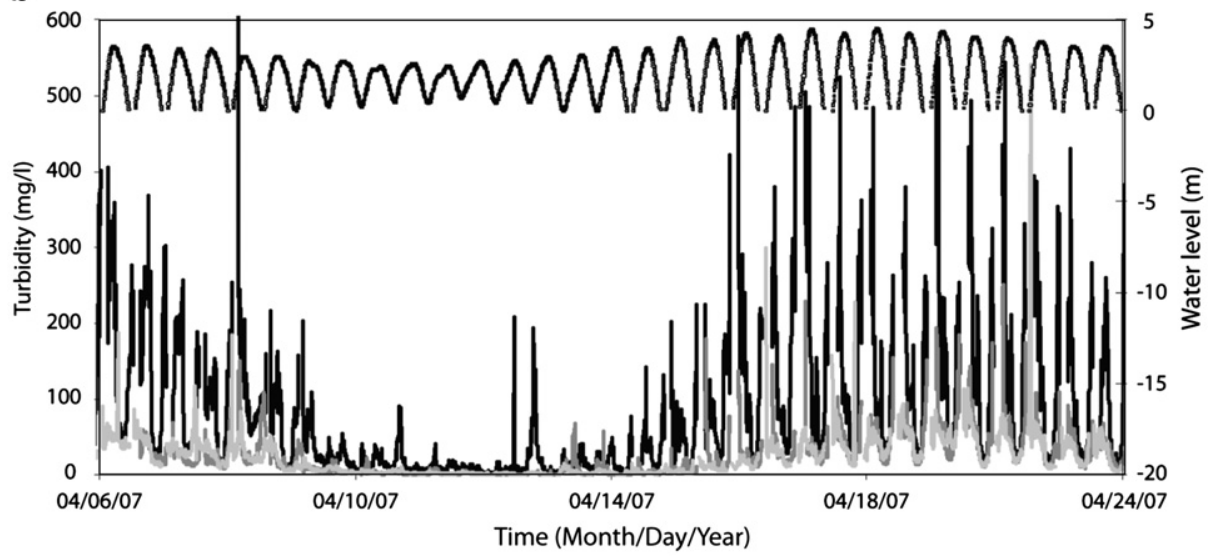

Fig. 2. Variability of (a) salinity and (b) turbidity on Brouage mudflat, the Doux and Agnas bank, from 04/06/07 to 04/24/07.
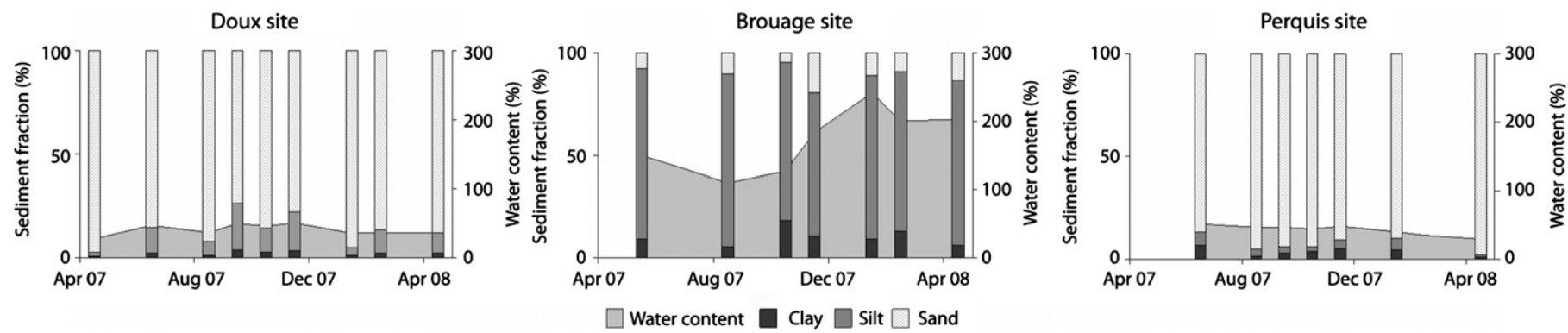

Fig. 3. Sediments fractions and water contents measured in sediments from Les Doux, Brouage and Perquis sites during the year survey. 
respectively) and constant over the survey. On the other hand, Brouage muddy sediments showed a muddy sediments with a mean fine fraction of $90 \%$ throughout the year and a mean median grain size of $9 \mu \mathrm{m}$. However, the water content varied, and presented low water content ( $<150 \%$ ) from April 2007 to October 2007 and higher water content ( $>$ 184\%) from November 2007 to April 2008.
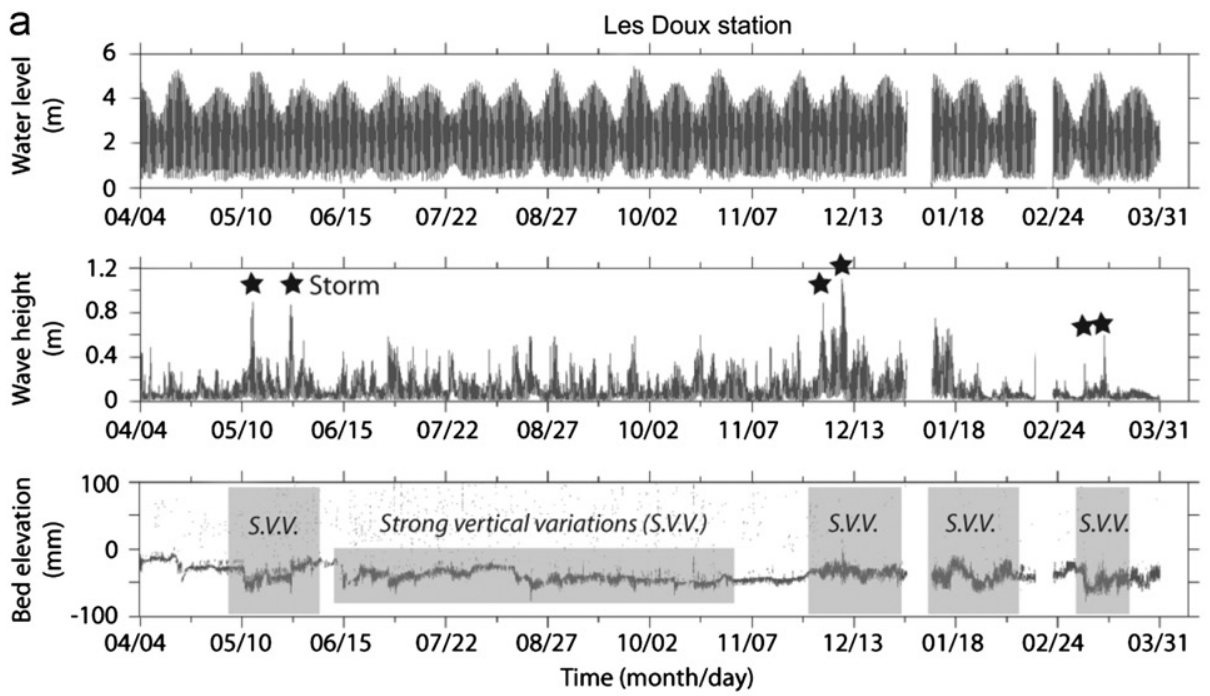

b

Brouage station
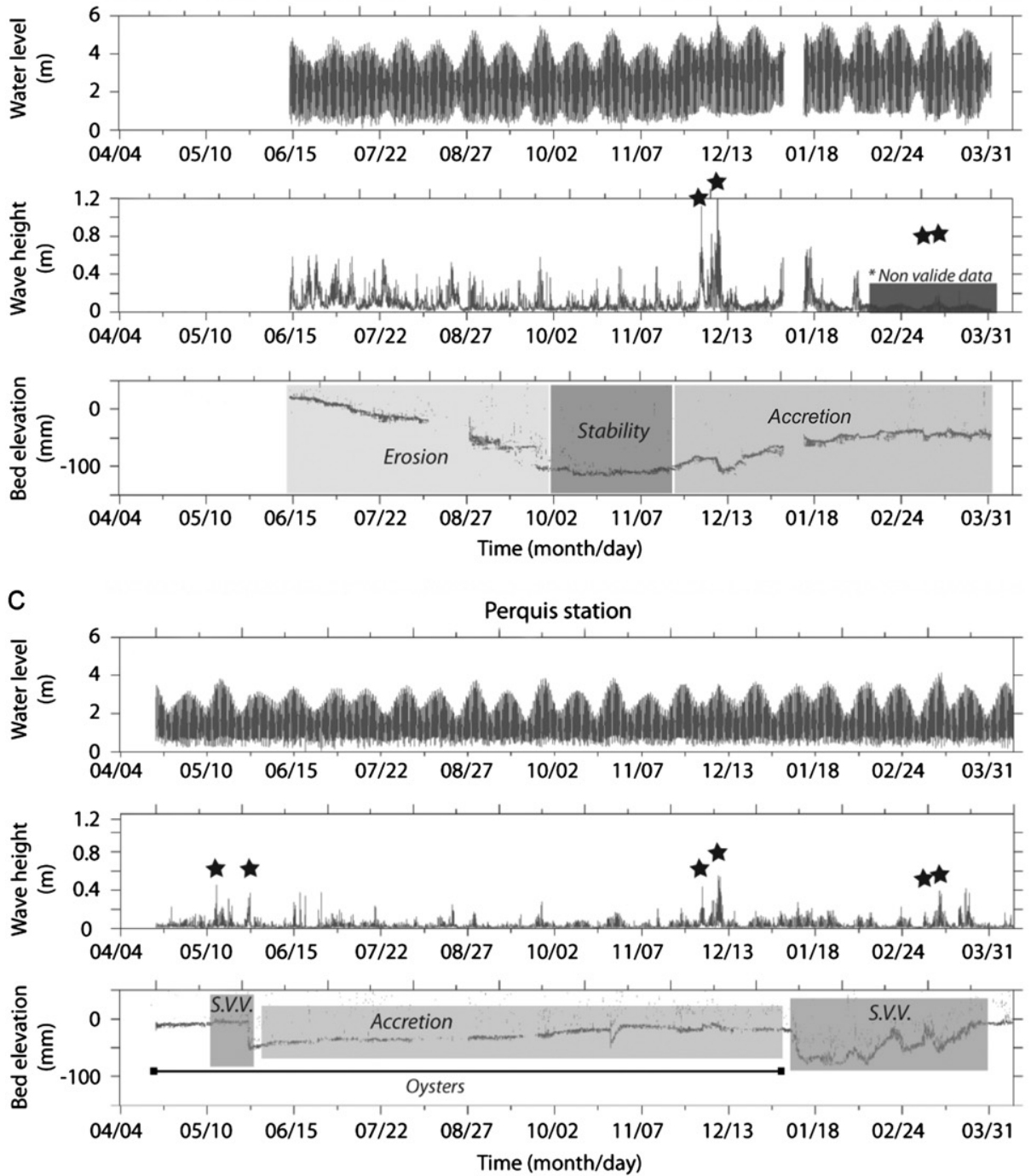

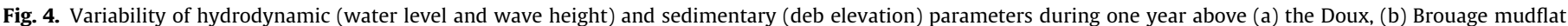
and (c) Perquis bank. 


\subsection{Bed elevation variation and wave activity}

At Les Doux area, bed elevation showed strong multi-centimeter vertical variations (SVV), which were related to wave's height and period (Fig. 4a). In fact, measured waves were established from a little signification from 0.20 to $0.50 \mathrm{~m}$ high throughout the year survey. During storms, recorded bed elevation was stronger, corresponding to current and wave ripples on the bottom.

At Brouage area, bed elevation and wave's height temporally changed (Fig. 4b). So, the mudflat was in constant erosion $(\Delta h=-100 \mathrm{~mm})$ from June 2007 to the end of August 2007, then stable from September 2007 to late November 2007 and in accretion (silting up) from December 2007. In the meantime, measured wave's activity was from a value of 0.20 to $0.70 \mathrm{~m}$ between May 2007 to August 2007, thus until $1.10 \mathrm{~m}$ (important activity) from December 2007 to the end of the survey: between these two periods, the waves were not significant.

In the southern Bay (Fig. 4c), at Perquis area, sediment interface was in slight accretion $(\Delta h=+35 \mathrm{~mm})$ from June 2007 to December 2007, whereas waves were not significant during the year $\left(H_{s}<0.20 \mathrm{~m}\right)$. However, during storm period, recorded wave heights were from 0.20 to $0.60 \mathrm{~m}$, in relation with higher altimetry variations (erosion and accretion), which is characteristic with current ripples propagation.

\subsection{Trace metal concentrations in Marennes-Oléron Bay sediments}

Particulate trace metal concentrations ( $\mathrm{Ni}, \mathrm{Cu}, \mathrm{Zn}, \mathrm{As}, \mathrm{Ag}, \mathrm{Cd}$, $\mathrm{Hg}, \mathrm{Pb}$ and $\mathrm{Th}$ ) varied spatially and temporally from May 08 to April 08 in the Marennes Oléron Bay surface sediments (Fig. 5a). As no similar concentrations range and temporal variation were observed between sites, trace metal variation are described for each site.

\subsubsection{Les Doux}

Trace metal concentration ranges observed at Les Doux were lower than at Brouage and Perquis. All trace metals significantly varied over time with a standard error of mean (SEM) varying from $10 \%$ to $30 \%$ and $\mathrm{Cu}$ presented a punctual elevated concentrations in September 07 (30\% < SEM < 50\%).

\subsubsection{Brouage}

Trace metal concentration ranges measured in Brouage were higher than at Les Doux and Perquis. Temporal variations were observed for $\mathrm{Zn}, \mathrm{As}, \mathrm{Ag}$ and $\mathrm{Cd}(10 \%<\mathrm{SEM}<30 \%)$ whereas $\mathrm{Ni}, \mathrm{Cu}$ and $\mathrm{Hg}$ were relatively constant $(\mathrm{SEM}<10 \%)$. Pb showed medium temporal variations $(30 \%<$ SEM $<50 \%)$.

\subsubsection{Perquis}

High temporal variations were observed for $\mathrm{Ni}, \mathrm{Cu}, \mathrm{Zn}, \mathrm{Ag}, \mathrm{Cd}$ (SEM $>50 \%)$ and for $\mathrm{As}, \mathrm{Pb}$ and $\mathrm{Hg}(30 \%<\mathrm{SEM}<50 \%)$. The lowest metal concentrations were observed in January 08 and the highest were observed in August 07 for $\mathrm{Cr}, \mathrm{Ni}$, and As concentrations and in September 07 for $\mathrm{Cu}, \mathrm{Zn}, \mathrm{Ag}, \mathrm{Cd}$ and $\mathrm{Pb}$. Exceptional high $\mathrm{Cd}$ contents exceeding Brouage and Les Doux levels were noticed in August and September 07.

Despite spatial and temporal metal variations, Cd showed punctual high concentrations at Les Doux and Perquis and was distinguished from other trace metals.

\section{Discussion}

\subsection{Trace metal concentrations in surface sediments}

The sampling strategy, adapted to the three environments of the Bay (Tesson, 1973; Pouliquen, 1975), allowed to observe and compare spatial and temporal variations of metal concentrations in the Bay. First of all, trace metal concentrations in sediments varied spatially (Fig. 5a). Higher metal concentrations were observed in muddy-sediments from the eastern part than sandy sediments from the western and southern parts of the bay. Those observations are consistent with increasing metal-adsorption sites with decreasing grain size described in the literature (Loring, 1991; Horowitz et al., 1999). The sampling strategy pointed out different temporal metal distributions between sites. In fact, in the east and western part, metal concentrations variations were closely related to sediment fractions (Fig. 3) and median grain size distribution whereas in the southern part accentuated temporal variations were observed with higher concentrations in September/October 07.

In the late 1980 s, a previous study on trace metal concentrations $(\mathrm{Cu}, \mathrm{Zn}, \mathrm{Cd}, \mathrm{Hg}$ and $\mathrm{Pb}$ ) in MOB sediments showed homogenous distribution between the eastern and western part of the MOB (Gonzalez et al., 1991). Sediments were sampled at one time, close to Brouage and Les Doux sites which were characterized at this period by homogenous grain size distribution (mean: $10 \mu \mathrm{m}$; minima: $8 \mu \mathrm{m}$; maxima: $15 \mu \mathrm{m}$; (Gonzalez et al., 1991)). As the same analytical procedure were performed in both studies (acid digestion $\mathrm{HNO}_{3}+\mathrm{HCl}+\mathrm{HF}$ for $\mathrm{Cu}, \mathrm{Zn}, \mathrm{Cd}, \mathrm{Pb}$ analysis and cold-vapor atomic spectrometry for $\mathrm{Hg}$ ) (Toth and Ingle, 1977; Sturgeon et al., 1982), we have compared this previous study to Brouage sediments (mean: $9 \mu \mathrm{m}$; minima: $7 \mu \mathrm{m}$; maxima: $12 \mu \mathrm{m})$ in order to provide a decadal tendency of trace metal concentration variations in the MOB sediments. Thus, $\mathrm{Cu}$ and $\mathrm{Hg}$ values were close to Brouage mean concentrations, $\mathrm{Cd}$ and $\mathrm{Zn}$ appeared to decrease over time whereas $\mathrm{Pb}$ to increase. However, we have to keep in mind that (i) the previous study (Gonzalez et al., 1991) presented only a spatial distribution and that (ii) present temporal variations in the MOB are significant. Thus, taking into account the annual variability, (i) $\mathrm{Cu}, \mathrm{Hg}$ and $\mathrm{Zn}$ are in the same concentration range and do not present decadal variations, (ii) Cd slightly decreased over the last two decades and (iii) $\mathrm{Pb}$ is in a steady state in the case of excluding its exceptional local increase in May 07. Those observations suggest a double balanced process, between (i) the removal of metal from the water column, estuaries and coastal inputs into the sediments and (ii) the metal inputs (diffusion, desorption) from the sediments to the water column. Present metal concentrations observed in the MOB are relatively low, in comparison to lagoon, bay and marine environments of world oceans reported in literature (Accornero et al., 2008), and can consequently be classified as an uncontaminated system as Vaccares and Leucate Mediterranean Lagoon in the Gulf of Lion (France) (RNO, 1998; Accornero et al., 2008).

Thus, the MOB is a highly dynamic system with significant spatial and temporal metal distribution variations. The sampling strategy in such environment is a key factor to provide a comprehensible overview of the ecosystem state. To assess the sediment quality, the influence of grain size distribution on metal concentrations (Horowitz et al., 1991; Loring, 1991) needs to be removed by using the enrichment factor parameter.

\subsection{Enrichment factor}

The degree of metal enrichment in sediments was assessed using the enrichment factor, (EF) which allow to differentiate natural geochemical background to anthropogenic inputs 

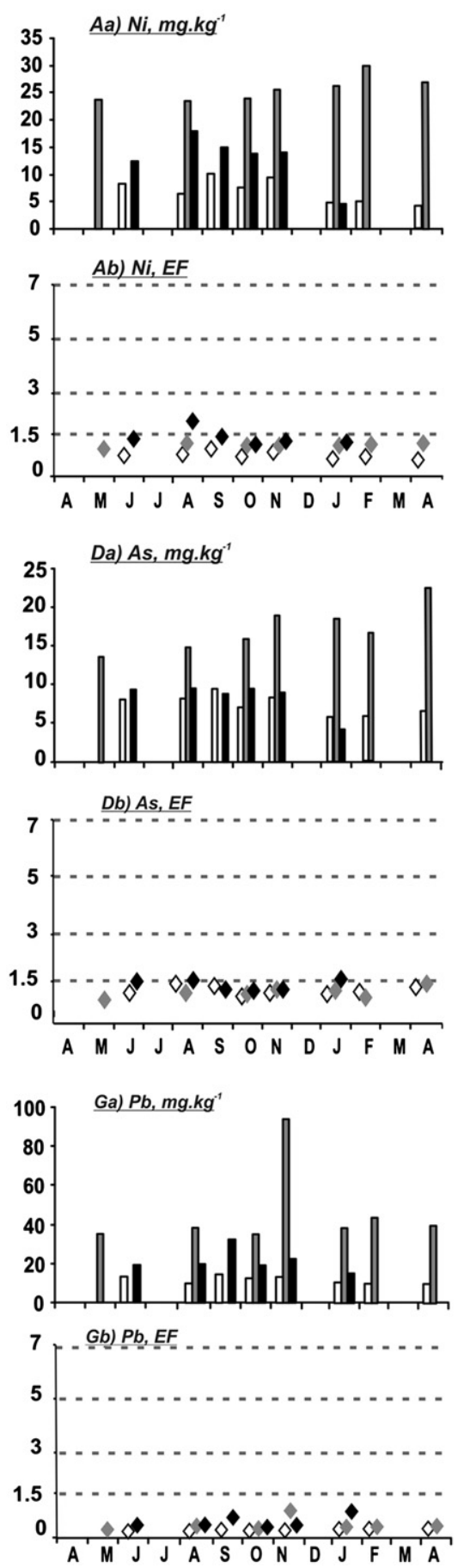
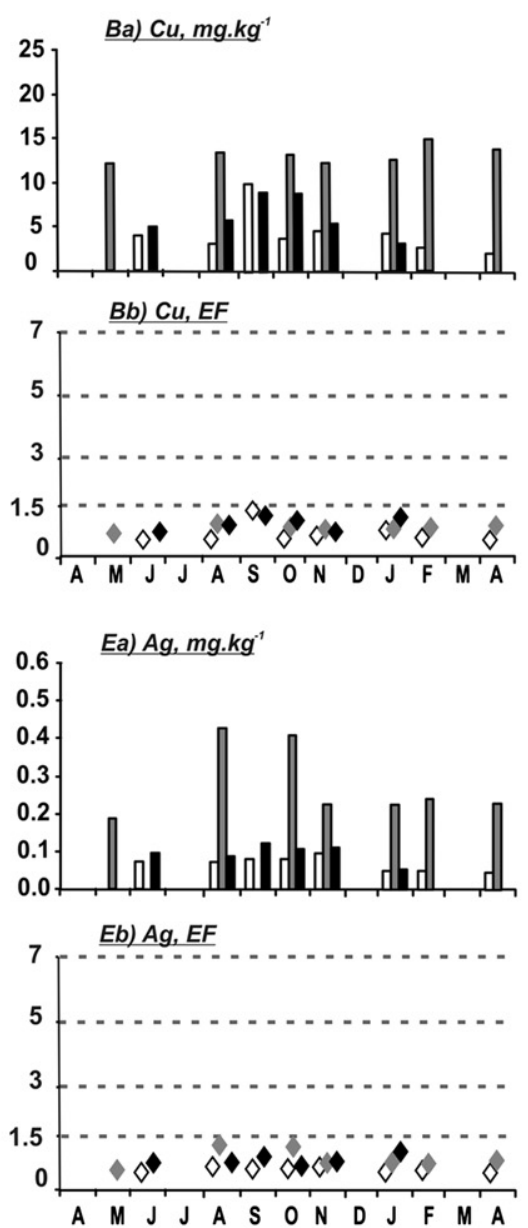

Ha) $\mathrm{Hg}, \mathrm{mg} \cdot \mathrm{kg}^{-1}$

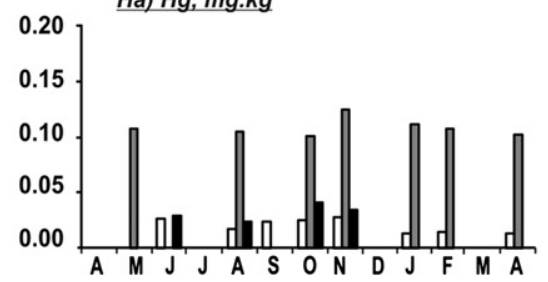

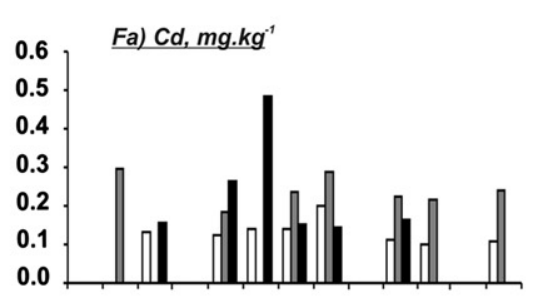
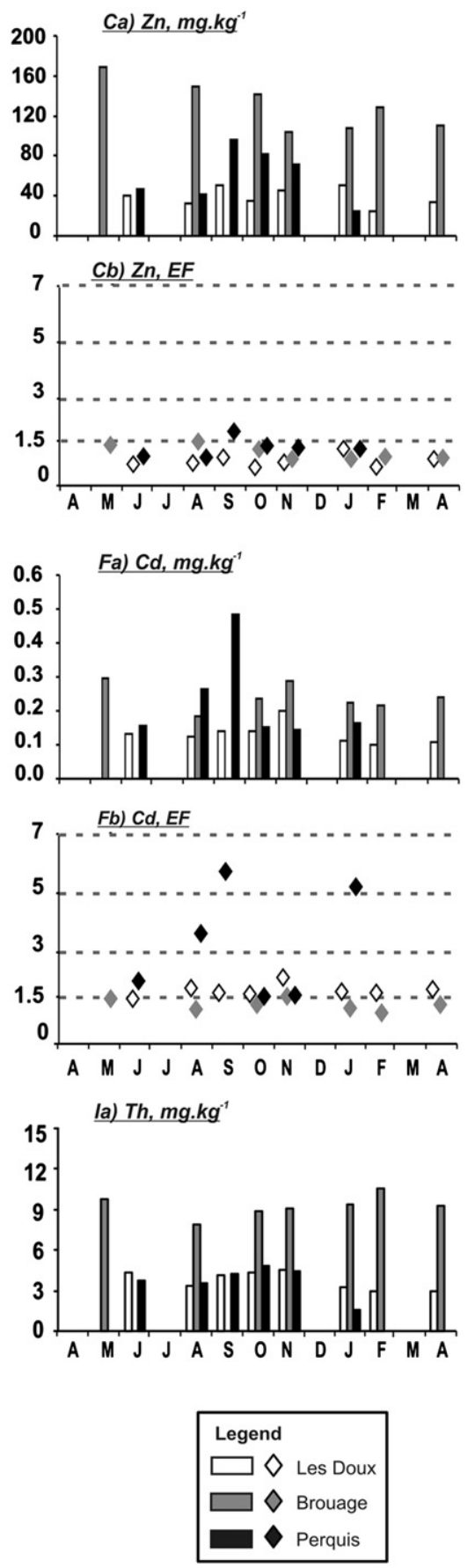

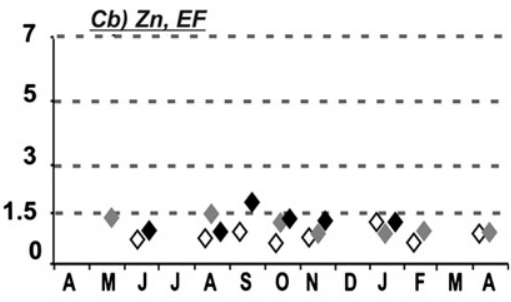

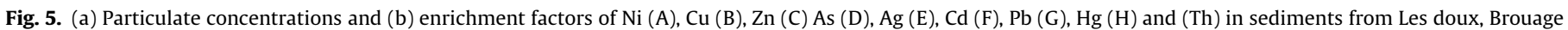
and Perquis. To notice, enrichment factors data are not available for $\mathrm{Hg}$ and $\mathrm{Th}$.

(Zhang and Liu, 2002). Previously, trace metal concentrations in sediments were normalized to compensate natural variability due to grain-size variations (e.g. mineral composition) and to detect any anthropogenic metal contributions e.g. (Loring, 1991). Grain size dependent effect was corrected using thorium (Th) concentrations. In fact, previous work showed that Th can be used as a conservative lithogenic element (Braun et al., 1993; Krachler and Shotyk, 2004; Coynel et al., 2007; Kipp et al., 2009), especially in the Gironde Estuary watershed (Masson et al., 2006; Coynel et al., 2007; Larrose et al., in press), because of its low solubility (e.g. van Calsteren and Thomas, 2006) and its limited reactivity (Martínez-Aguirre et al., 1995). Then, EF was defined as the ratio of Th normalized metal concentrations in sediments over Th normalized ratio in a geochemical background reference (Feng et al., 2004). The background reference concentrations correspond to the concentrations measured at the bottom of a sediment core from the West Gironde Mud Patch (Larrose et al., in press), located on the Aquitaine Plateau, seaward of the Gironde estuary mouth (Lesueur et al., 2001), and considered as the regional geochemical baseline for sediments derived from the Gironde Estuary (Larrose et al., in press). Thus, a value of EF between 0.5 and 1.5 suggests natural weathering processes (Zhang and Liu, 2002). In contrary, EF $>1.5$ values suggest enrichment from anthropogenic source. More precisely, the 
$1.5<\mathrm{EF}<3$ interval indicates a minor enrichment, the $3<\mathrm{EF}<5$ one for a moderate enrichment, the $5<\mathrm{EF}<10$ one for a moderately severe enrichment until $\mathrm{EF}>50$ values which indicates an extremely severe enrichment (Essien et al., 2009). Enrichment factor determined in sediments from Les Doux, Brouage and Perquis were reported in Fig. 5b. Three tendencies were observed (i) elements as $\mathrm{Cu}, \mathrm{As}, \mathrm{Ag}$ and $\mathrm{Pb}$ which are in the geochemical background in the East, West and South part of the bay (Fig. 5b-B, D, E and G) (ii) elements as $\mathrm{Ni}$ and $\mathrm{Zn}$ which are in the geochemical background in the East and West of the Bay and which present temporal minor enrichment in the south (Fig. 5b-A and C) and (iii) Cd which is in the geochemical background in the East, which present minor enrichment in the West and minor to temporally moderate severe enrichment in the south of the Bay (Fig. 5b-F). Thus, metal enrichment factors showed that metal sediment quality strongly spatially differed. Thus, to better understand metal distribution in the Bay, we will focus on Cd because of its variation and its high pollutant state in the Bay (Cd repercussion on oysters' production) and we will examine its temporal distribution coupled to hydrodynamic forcing for each site.

\subsection{Hydrodynamics}

The Marennes Oléron Bay showed spatial and temporal strong hydrodynamic and sedimentation variations. In the western part, sediment interface was rather sandy and was characterized by pluri-centimeter erosion and accretion events (Fig. 4a). These sedimentary movements depend of wave's characteristics (wave's height, period and direction). The area was under strong oceanic influence as evidenced measured salinity (34 Fig. 2a situation C). However, during particular periods, less salty water coming from the Gironde was directly measured (Fig. 2a-situation B) and were simulated after this records, using PREVIMER hydrodynamic

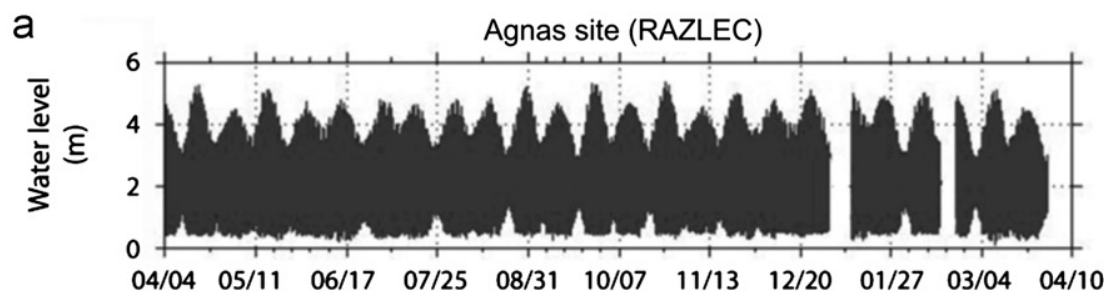

b
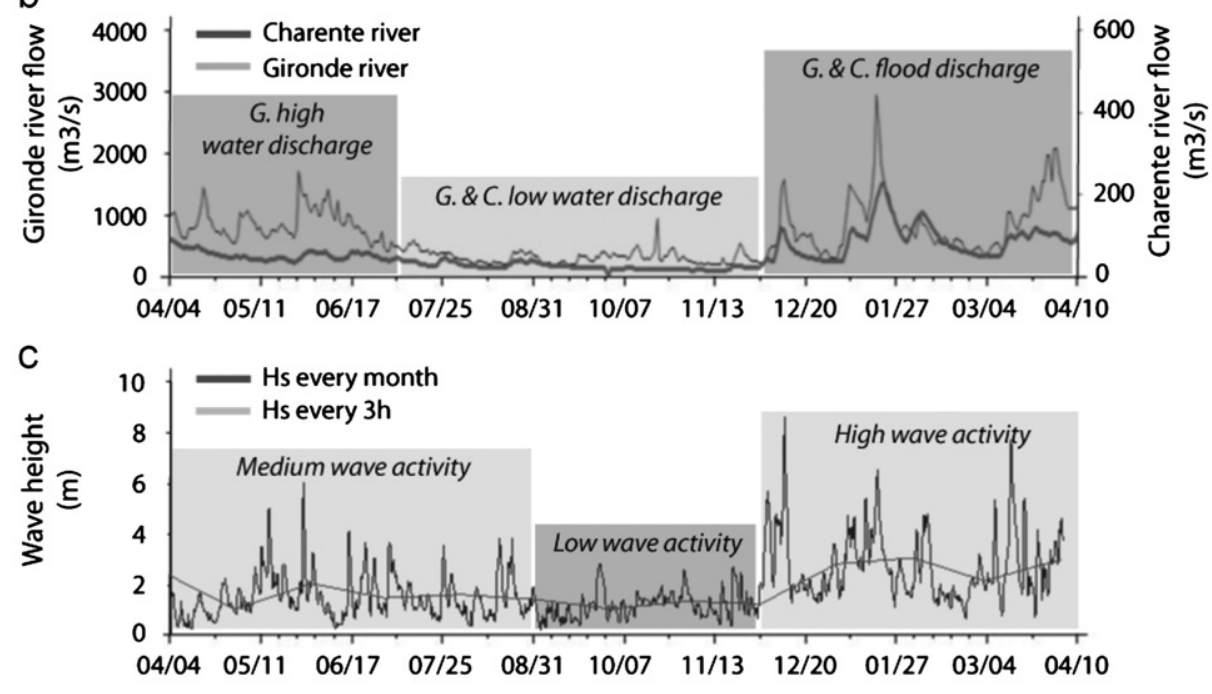

d

Brouage site
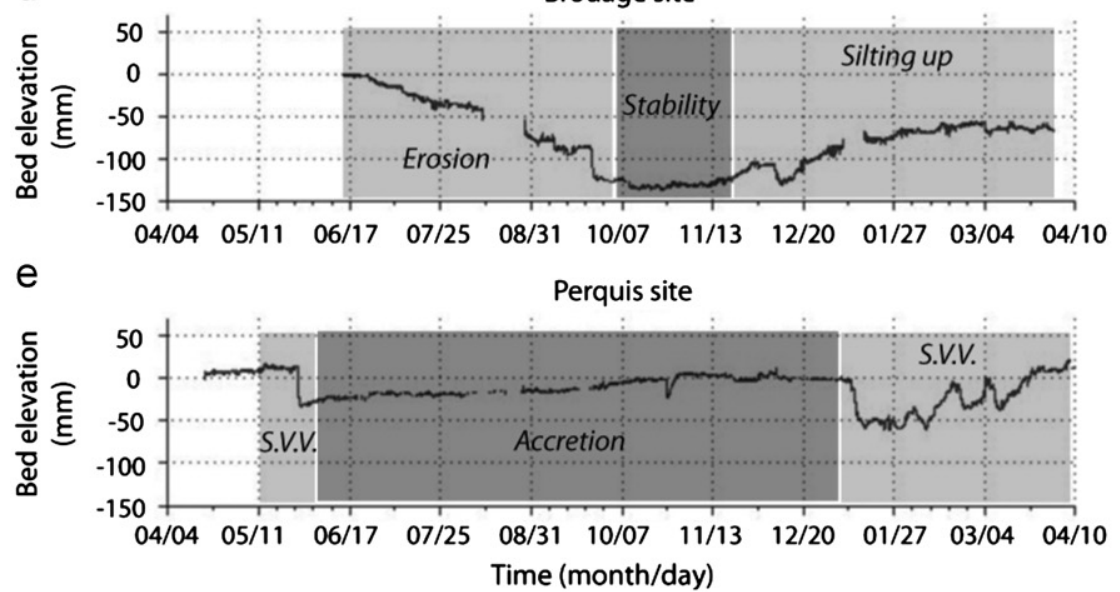

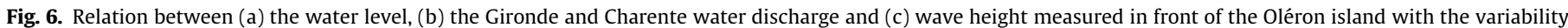
of the bed elevation on (d) Brouage mudflat and (e) Perquis bank, during one year. 
model (IFREMER) based on daily measured salinity. These observations are in agreement with previous studies on the Gironde influence on MOB sediment via the Antioche Strait (Pouliquen, 1975; Castaing and Allen, 1981; Boutier et al., 1989; Froidefond et al., 1998; Parra et al., 1999) and with Cd minor enrichment estimated on Les Doux sediments. In fact, during the transit Gironde-Antioche-MOB, Cd-enriched SPM originated from the Gironde Estuary desorbed in marine coastal waters (Boutier et al., 2000; Masson, 2007; Dabrin, 2009, Strady et al., in press) and deposited as low Cd-concentrated SPM in the western MOB (Fig. 5c).

In contrast, the eastern MOB mudflat was largely influenced by the Charente River Estuary (Tesson, 1973; Pouliquen, 1975). Salinity, turbidity and bed elevation variations (Figs. 4 and 7b) differed from the western part showing disconnection of hydrodynamic and sedimentary parameters. During the survey, bed elevation was closely related to Charente water discharges and wave activity (Fig. 6b-d), as we observed erosion during high and low water discharges from April 07 to October 07 and repeated short wave action and accretion during mean water discharges and decreasing wave activity from December 07 to April 08 . Accordingly, sediments sampled during accretion presented high water content (Fig. 3) and were freshly deposited (called 'mollin') whereas during erosion, sampled sediments presented lower water content (Fig. 3) and were dated from 50 to $100 \mathrm{yr}$, as shown by ${ }^{210} \mathrm{~Pb}$ datation (Kervella, 2010). During flood, expulsion of maximum Charente River turbidity caused deposition a few days later in the mudflat (Fig. $6 \mathrm{~b}$ and e), as observed in the Seine Estuary (Deloffre et al., 2005). However, Cd concentrations and enrichment were constant over time and were not related to the age of sediments and to Charente River Estuary water discharges. Thus, inputs of trace metal to Brouage mudflat were constant over the survey, meaning constant trace metal inputs from the Charente River, whatever the water discharges. Concerning the older sediment, low trace metal concentrations can be explained by sediment desorption during regular outcrop since a century and probably already not metal-enriched SPM flowing out the Charente Estuary.

The southern part of the bay showed different hydrodynamic and sedimentation processes (Fig. 4c). This area was very quiet with low waves amplitude, and did not exhibit close relation with bed elevation variations, except during major storm. During the year, the area was in net accretion despite multi-centimeter sequences of erosion/deposition observed in winter (Fig. 6b, c and f). From December 28, 2007, oyster installations were removed and could have induced development of current ripples as they did not act as hydrodynamic barriers anymore. Before this event, sandy bed-elevation variations were not related to the Charente and Gironde water discharges or to tidal cycles (Fig. 6a and b). However, we observed that the outside waves were much higher (mean $H_{s}: 3 \mathrm{~m}$; Fig. $6 \mathrm{c}$ ) during winter than during summer time (mean $H_{s}: 1.8 \mathrm{~m}$; Fig. $6 \mathrm{c}$ ), which could have induced sand resuspension and transport from outside dunes to the MOB via the Maumusson Strait. Cadmium enrichments in sediments from Perquis were the most important of the MOB. Enrichments temporally varied but were not related to temporal bed elevation variations (Figs. 5 and 3). Because of the north to south residual circulation, the Charente origins of enriched sediments could be considered. However, Cd enrichments in the south were significantly higher than in Brouage and Les Doux, refuting their possible origins from the northern Bay. Thus, we hypothesized $\mathrm{Cd}$ sediment enrichment by deposition of high Cd-concentrated SPM transported by the Gironde Estuary via the Maumusson Strait. In fact, the Gironde turbid plume can extend northly to the coast during high water discharges and flood situations combined from S to SE winds (Froidefond et al., 1998; Hermida et al., 1998).
The connection of the Gironde turbid plume with the Maumusson Strait was estimated from a statistical study of satellite images over four years at about 30\% of time per year (Dabrin, 2009; Lafon et al., 2009). Thus, SPM from the Gironde plume can enter the Bay through Maumusson Strait during those specific conditions (Dabrin, 2009, Strady et al., in press, Chemosphere) and flooding tide (Bertin et al., 2005). This is consistent with moderately severe enriched Cd observed in January 08 (Fig. 5) just after the Gironde flood situation (Fig. 6b).

Bed elevation, wave activity and grain size distribution surveys at the three sites were highly relevant to characterise sediment dynamic and showed hydrodynamic forcing plays an important role on sediment bed elevation and erosion/sedimentation phases and influence trace metal distribution. In fact, sediments were in constant good quality state in the eastern part and were influence neither by the Charente river water discharges or the wave activities. In contrast, sediments from the western parts were strongly related to waves activities whereas metal concentrations were more related to water masses inputs, especially the Gironde water influence. Finally, the southern part presented different hydrodynamic and enrichment patterns as sediment quality was punctually moderately severe enriched in $\mathrm{Cd}$ in relation with Gironde water discharges. To resume, a conceptual outline is presented in Fig. 7 and represents the Gironde and Charente influences on metal distribution and the hydrodynamic influences via the Gironde and Charente water discharges and wave propagation on sediment dynamic in the Bay.

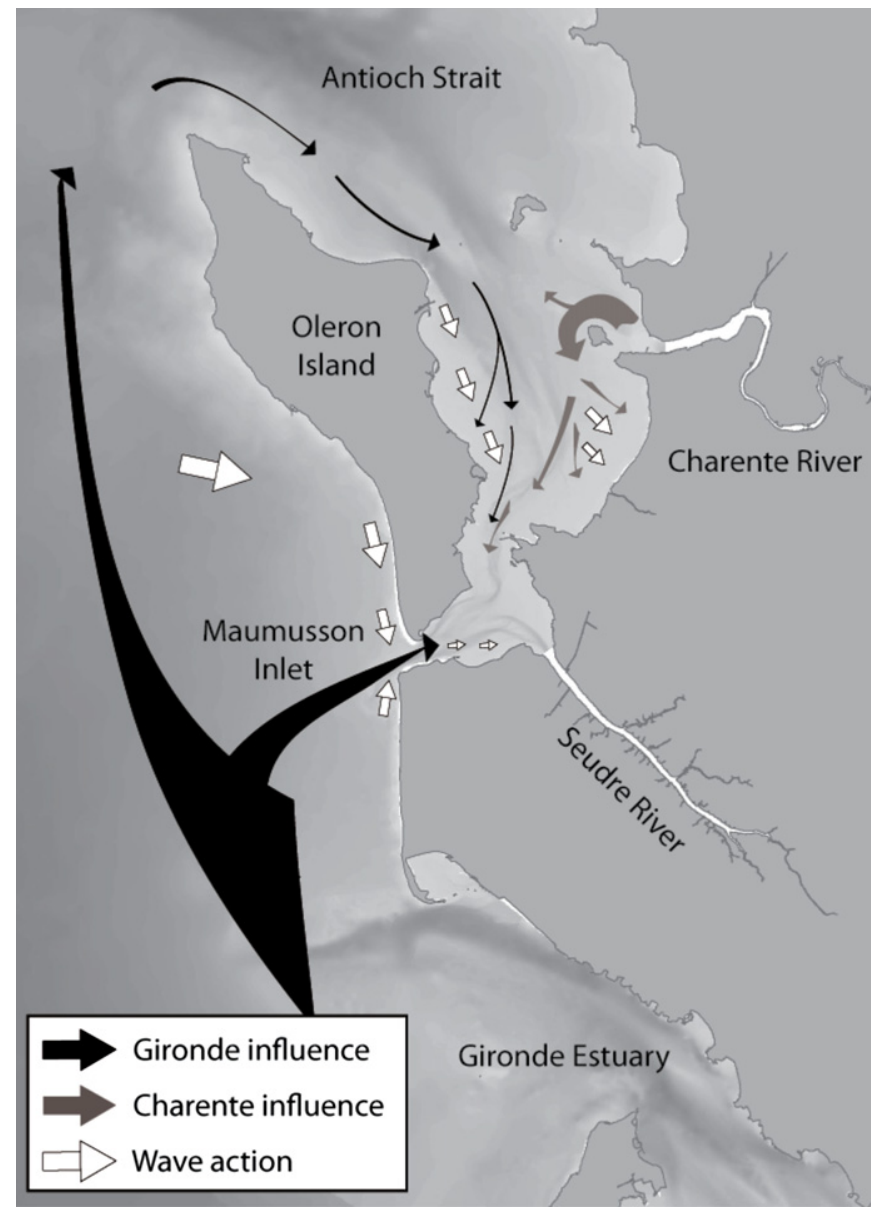

Fig. 7. Conceptual outline of the influence of the Gironde Estuary, Charente Estuary and wave action on spatial and temporal variability of sediment transport and $\mathrm{Cd}$ concentrations in surface sediments. The thickness of the arrows is relatively proportional to the Cd contribution to the Marennes Oléron Bay. 
Globally, this pluri-disciplinary approach allows pointing out the temporal variability of sediment characteristics and their trace metal contents. In most coastal marine environments, trace metal concentrations in sediments varied spatially and temporally in an annual scale (e.g. Essien et al., 2009; Corbett et al., 2009, Valdès et al., 2009). However, in areas highly influenced by tides, currents and water discharges, we rather think that temporal variability, even on a small day scale, are important to understand the dynamic of the system. The approach described in this paper can thus be broaden to dynamic environments in order to (i) point out and characterise temporal changes and (ii) determine the factors which are controlling the temporal and spatial variability of sediments and their trace metal concentrations.

\section{Conclusion}

This original pluri-disciplinary study pointed out both spatial and temporal trace metal concentrations in sediments of the Marennes Oléron Bay, the sediment quality and the role of regional hydrodynamics forcing on metal distribution in sediments. The MOB can be divided into three areas, western, eastern and southern, disconnected to each other, which are characterized by specific hydrodynamic forcing and trace metal distribution. Globally, sediments were little impacted by trace metals which were in the geochemical background state and so in good quality state. However, the southern Bay was the most concerned by metal enrichment. Temporal distribution variations have shown the influence of the Gironde plume via the Maumusson Strait on Cd enrichment, which was under-estimated until now. To conclude, this study has shown the relevance of an adapted sampling strategy and multi-disciplinary approach to assess metal sediment quality and later implement an ecosystem management.

\section{Acknowledgments}

The authors thank Lucette Joassard for the grain size distribution analysis. The study was funded by the laboratory IFREMER LERPC, the Conseil Général de Charente-Maritime and the Région Poitou-Charente and the VOTR'TRAM EC2CO INSU program.

\section{References}

Accornero, A., Gnerre, R., Manfra, L., 2008. Sediment concentrations of trace metals in the Berre lagoon (France): an assessment of contamination. Archives of Environmental Contamination and Toxicology 54, 372-385.

Apitz, S.E., 2008. Is risk-based, sustainable sediment management consistent with European policy? Journal of Soils and Sediments 8, 461-466.

Apitz, S.E., Power, E.A., 2002. From risk assessment to sediment management: an international perspective. Journal of Soils and Sediments 2, 61-66.

Audry, S., Blanc, G., Schäfer, J., 2004a. Cadmium transport in the Lot-Garonne River system (France) - temporal variability and a model for flux estimation. Science of the Total Environment 319, 197-213.

Audry, S., Grosbois, C., Bril, H., Schäfer, J., Kierczak, J., Blanc, G., 2010. Postdepositional redistribution of trace metals in réservoir sédiments of a mining/ smelting-impacted watershed (the Lot River, SW France). Applied Geochemistry 25, 778-794.

Audry, S., Schäfer, J., Blanc, G., Bossy, C., Lavaux, G., 2004b. Anthropogenic components of heavy metal $(\mathrm{Cd}, \mathrm{Zn}, \mathrm{Cu}, \mathrm{Pb})$ budgets in the Lot-Garonne fluvial system (France). Applied Geochemistry 19, 769-786.

Bassoullet, P., Le Hir, P., Gouleau, D., Robert, S., 2000. Sediment transport over an intertidal mudflat: field investigations and estimation of fluxes within the 'Baie de Marennes-Oleron' (France). Continental Shelf Research 20, 1635-1653.

Bertin, X., Chaumillon, E., Sottolichio, A., Pedreros, R., 2005. Tidal inlet response to sediment infilling of the associated bay and possible implications of human activities: the Marennes-Oléron Bay and the Maumusson Inlet, France. Continental Shelf Research 25, 1115-1131.
Blanc, G., Lapaquellerie, Y., Maillet, N., Anschutz, P., 1999. A cadmium budget for the Lot-Garonne fluvial system (France). Hydrobiologia 410, 331-341.

Borja, A., Valencia, V., Franco, J., Muxika, I., Bald, J., Belzunce, M.J., Solaun, O., 2004 The water framework directive: water alone, or in association with sediment and biota, in determining quality standards? Marine Pollution Bulletin 49, 8-11.

Boutier, B., Chiffoleau, J., Jouanneau, J., Latouche, C., Phillips, I., 1989. La contamination de la Gironde par le cadmium: origine, extension, importance. pp. Scientific and Technical Report. Ifremer no. 14.

Boutier, B., Chiffoleau, J.F., Gonzalez, J.L., Lazure, P., Auger, D., Truquet, I., 2000 Influence of the Gironde Estuary outputs on cadmium concentrations in the coastal waters: consequences on the Marennes-Oléron bay (France). Oceanologica Acta 23, 745-758.

Braun, J.J., Pagel, M., Herbilln, A., Rosin, C., 1993. Mobilization and redistribution of REEs and thorium in a syenitic lateritic profile: a mass balance study. Geochimica et Cosmochimica Acta 57, 4419-4434.

Castaing, P., Allen, G.P., 1981. Mechanisms controlling seaward escape of suspended sediment from the Gironde: a macrotidal estuary in France. Marine Geology 40, 101-118.

Corbett, D.R., Walsh, J.P., Marciniak, K., 2009. Temporal and spatial variability of trace metals in sediments of two adjacent tributaries of the Neuse River Estuary, North Carolina, USA. Marine Pollution Bulletin 58 1739-1747.

Coynel, A., Blanc, G., Marache, A., Schäfer, J., Dabrin, A., Maneux, E., Bossy, C. Masson, M., Lavaux, G., 2009. Assessment of metal contamination in a small mining- and smelting-affected watershed: high resolution monitoring coupled with spatial analysis by GIS. Journal of Environmental Monitoring 11 962-976.

Coynel, A., Schäfer, J., Blanc, G., Bossy, C., 2007. Scenario of particulate trace metal and metalloid transport during a major flood event inferred from transient geochemical signals. Applied Geochemistry 22, 821-836.

Crane, M., 2003. Proposed development of sediment quality guidelines under the European Water Framework Directive: a critique. Toxicology Letters 142 195-206.

Dabrin, A., 2009. Mécanismes de Transfert des Éléments Traces Métalliques et Réactivité Estuarienne. Cas des Systèmes Gironde, Charente, Seudre et Baie de Marennes Oléron. Thèse, University of Bordeaux, p. 375.

Dabrin, A. Schäfer, J., Blanc, G., Strady, E., Masson, M., Bossy, C., Castelle, S. Girardot, N., Coynel, A., 2009. Improving estuarine net flux estimates for dissolved cadmium export at the annual timescale: application to the Gironde Estuary. Estuarine, Coastal and Shelf Science 84, 429-439.

Deloffre, J., Lafite, R., Lesueur, P., Lesourd, S., Verney, R., Guézennec, L., 2005. Sedimentary processes on an intertidal mudflat in the upper macrotidal Seine estuary, France. Estuarine, Coastal and Shelf Science 64, 710-720.

Essien, J.P., Antai, S.P., Olajire, A.A. 2009. Distribution, seasonal variations and ecotoxicological significance of heavy metals in sediments of cross river estuary mangrove swamp. Water, Air, and Soil Pollution 197, 91-105.

Feng, H., Han, X., Zhang, W., Yu, L., 2004. A preliminary study of heavy meta contamination in Yangtze River intertidal zone due to urbanization. Marine Pollution Bulletin 49, 910-915.

Förstner, U., Salomons, W., 2008. Trends and challenges in sediment research 2008: the role of sediments in river basin management. Journal of Soils and Sediments 8, 281-283.

Froidefond, J.M., Jegou, A.M., Hermida, J., Lazure, P., Castaing, P., 1998. Variability of the Gironde turbid plume by remote sensing. Effects of climatic factors. Oceanologica Acta 21, 191-207.

Galois, R., Blanchard, G., Seguignes, M., Huet, V., Joassard, L., 2000. Spatial distribution of sediment particulate organic matter on two estuarine intertida mudflats: a comparison between Marennes-Oleron Bay (France) and the Humber Estuary (UK). Continental Shelf Research 20, 1199-1217.

Gonzalez, J.L., Boutier, B., Chiffoleau, J.F., Auger, D., Noel, J., Truquet, I., 1991. Distribution of $\mathrm{Cd}$ and $\mathrm{Hg}$ in the Bay of Marennes-Oleron. Oceanologica Acta $14,559-568$

Gouleau, D., Jouanneau, J.M., Weber, O., Sauriau, P.G., 2000. Short- and long-term sedimentation on Montportail-Brouage intertidal mudflat, Marennes-Oleron Bay (France). Continental Shelf Research 20, 1513-1530.

Goulletquer, P., Le Moine, O., 2002. Shellfish farming and Coastal Zone Management (CZM) development in the Marennes-Oléron Bay and Charentais Sounds (Charente Maritime, France): a review of recent developments. Aquaculture International 10, 507-525.

Guillaumont, B., 1991. Use of satellite imagery for spatial and temporal comparisons in the intertidal zone. 19. In: Proceedings of ECSA Symposium, Estuarine and Costal Sciences Association, Caen.

Hermida, J., Lazure, P., Froidefond, J.M., Jegou, A.M., Castaing, P., 1998. Seaward dispersion of Gironde estuarine waters on to Aquitanian continental shelf from hydrological, satellite and numeric data. Oceanologica Acta 21, 209-221.

Hily, C., 1977. Characteristics and originality of the Pertuis Charentais area. Journal of Recherche Oceanography 2, 31-38.

Horowitz, A.J., Elrick, K.A., Demas, C.R., Demcheck, D.K., 1991. The use of sedimenttrace element geochemical models for the identification of local fluvial baseline concentrations. In: Proceedings of Sediment and Stream Water Quality in a Changing Environment Symposium, Vienna, pp. 339-348.

Horowitz, A.J., Meybeck, M., Idlafkih, Z., Biger, E., 1999. Variations in trace elemen geochemistry in the Seine River Basin based on floodplain deposits and bed sediments. Hydrological Processes 13, 1329-1340. 
Jestin, H., Bassoullet, P., Le Hir, P., L'Yavanc, J., Degres, Y., 1998. Development of ALTUS, a high frequency acoustic submersible recording altimeter to accurately monitor bed elevation and quantify deposition or erosion of sediments. In: Proceedings of Oceans Conference Record (IEEE), pp. 189-194.

Jouanneau, J.M., Boutier, B., Chiffoleau, J.F., Latouche, C., Philipps, I., 1990 Cadmium in the Gironde fluvioestuarine system: behaviour and flow. Science of the Total Environment 97-98, 465-479.

Kervella, S., 2010. Dynamique des Sédiments Fins et Mixtes des Zones Intertidales de la Baie de MARENNES-Oléron-Caracterisation des Sédiments, Processus Hydro-Sédimentaires et Modélisation Appliquée. University of la Rochelle.

Kervella, S., Robert, S., Pantet, A., Jarny, S., 2009. Characterisation of Marennes Oléron bay superficial sediment. European Journal of Environmental and Civil Engineering 13, 261-281.

Kipp, G.G., Stone, J.J., Stetler, L.D., 2009. Arsenic and uranium transport in sédiments near abandoned uranium mines in Harding County, South Dakota. Applied Geochemistry 24, 2246-2255.

Klingebiel, A., Deresseghier, A., Tesson, M., 1971. Contribution à l'étude de la circulation des masses d'eau dans le bassin de Marennes-Oléron. Comptes Rendus de l'Academie de Sciences de Paris 273, 1783-1786.

Krachler, M. Shotyk, W., 2004. Natural and anthropogenic enrichments of molybdenum, thorium, and uranium in a complete peat bog profile, Jura Mountains, Switzerland. Journal of Environmental Monitoring 6, 418-426.

Kusuki, Y., 1978. Fundamental studies on the deterioration of oyster growing grounds. 3. Sinking rates and distance of transport of the faeces of Japanese oyster. Bulletin of Japan Society of Fishery Science 44, 971-973.

Lafon, V., Petus, C., Dabrin, A., Froidefond, J.M., Doxaran, D., Maneux, E., Castaing, P. 2009. Gironde and Adour plume dynamics using MODIS imagery-dynamique des panaches de la Gironde et de l'Adour par imagerie MODIS. 31èmes Journée de l'Hydraulique de la SHF "Morphodynamique et gestion des sédiments dans les estuaires, les baies et les deltas", Paris, France.

Lapaquellerie, Y., Jouanneau, J.M., Maillet, N., Latouche, C., 1995. Cadmium pollution in sediments of the Lot river (France), estimate of the mass of cadmium. pollution en Cadmium dans les sédiments du Lot (France) et calcul du stock de polluant. Environmental Technology 16, 1145-1154.

Larrose, A., Coynel, A., Schäfer, J., Blanc, G., Massé, L., Maneux, E., 2010. Assessing the current state of the Gironde Estuary by mapping priority contaminant distribution and risk potential in surface sediment. Applied Geochemistry 25 1912-1923.

Latouche, C., 1988. Cadmium pollution in the Gironde estuary. La pollution en cadmium de l'estuaire de la Gironde 44, 15-21.

Lesueur, P., Jouanneau, J.M., Boust, D., Tastet, J.P., Weber, O., 2001. Sedimentation rates and fluxes in the continental shelf mud fields in the Bay of Biscay (France). Continental Shelf Research 21, 1383-1401.

Loring, D.H., 1991. Normalization of heavy-metal data from estuarine and coastal sediments. ICES Journal of Marine Science 48, 101-115.

Martínez-Aguirre, A., Garcia-León, M., Ivanovich, M., 1995. U and Th speciation in river sediments. Science of the Total Environment 173-174, 203-209.

Martin, J.L., Sornin, J.M., Delmas, D., El Sayed, M., Berthet, B., 1989. La biodéposition dans les aires conchylicoles. Son rôle dans la concentration de matière organique et de contaminants potentiels. Son impact sur le sédiment. IFREMER, 60.

Masson, M., 2007. Sources et Transferts Métalliques dans le Bassin Versant de la Gironde. Réactivité et Mécanismes Géochimiques dans L'estuaire Fluvial de la Gironde. Université Bordeaux1, p. 366.

Masson, M., Blanc, G., Schäfer, J., 2006. Geochemical signals and source contributions to heavy metal $(\mathrm{Cd}, \mathrm{Zn}, \mathrm{Pb}, \mathrm{Cu})$ fluxes into the Gironde Estuary via its major tributaries. Science of the Total Environment 370, 133-146.

Parra, M., Castaing, P., Jouanneau, J.M., Grousset, F., Latouche, C., 1999. Nd-S isotopic composition of present-day sediments from the Gironde Estuary, its draining basins and the WestGironde mud patch (SW France). Continental Shelf Research 19, 135-150.

Pantet, A., Robert, S., Jarny, S., Kervella., S., 2010. Effect of coarse particle volume fraction on the yield stress of muddy sediments from Marennes-Oléron Bay. Advances in Materials Science and Engineering 2010, 6 Article ID 245398.

Pouliquen, M., 1975. Etude Minéralogique et Sédimentologique des Sédiments du Littoral Vendo-Charentais et de la Vasière Ouest-Gironde: Application à la Connaissance de L'origine et de la Dynamique des Vases dans la Baie de Marennes-Oléron. Université Bordeaux 1, France, p. 163.

RNO, 1998. Surveillance du milieu marin. Travaux du RNO. Ifremer et Ministère de l'Aménagement du territoire et de l'Environnement.

RNO, 2000. Surveillance du milieu marin. Travaux du RNO. Ifremer et Ministère de l'Ecologie et du Développement Durable.

RNO, 2006. Surveillance du milieu marin. Travaux du RNO. Ifremer et Ministère de l'Ecologie et du Développement Durable.

Sauriau, P.-G., Mouret, V., Rince, J.-P., 1989. Trophic system of wild soft-bottom molluscs in the Marennes-Oleron oyster-farming bay. Oceanologica Acta Paris 12, 193-204.

Schäfer, J., Blanc, G., 2002. Relationship between ore deposits in river catchments and geochemistry of suspended particulate matter from six rivers in southwest France. Science of the Total Environment 298, 103-118.

Soletchnik, P., Faury, N., Razet, D., Goulletquer, P., 1998. Hydrobiology of the Marennes-Oléron bay. Seasonal indices and analysis of trends from 1978 to 1995. Hydrobiologia 386, 131-146.

Sornin, J.M., 1981. Processus Sédimentaire et Biodéposition liés à Différents Modes de Conchyliculture (Baie de Cancale, Anse de l'Aiguillon et Bassin de Marennes-Oléron). Gironde. Institut des Sciences de la Nature de I'Université de Nantes, Nantes, p. 188.

Stanisière, J.-Y., Dumas, F., Plus, M., Maurer, D., Robert, S., 2006. Caractérisation des Composantes Hydrodynamiques d'un Système Côtier Semi-Fermé: Le Bassin de Marennes-Oléron. in: Ifremer, R. (Ed.).

Strady, E., Blanc, G., Baudrimont, M., Schäfer, J., Robert, S., Lafon, V., in press. Roles of regional hydrodynalic and trophic contamination in cadmium bioaccumulation by pacific oysters in the Marennes-Oléron Bay (France). Chemosphere, Corrected proof, doi:10.1016/j.chemosphere.2011.02.051.

Struski, C., 2005. Modélisation des Flux de Matières Dans la Baie de Marennes-Oléron: Couplage de L'hydrodynamisme, de la Production Primaire et de la Consommation par les Huîtres. Université de La Rochelle p. 340.

Sturgeon, R.E., Desaulniers, J.A.H., Berman, S.S., Russell, D.S., 1982. Determination of trace metals in estuarine sediments by graphite-furnace atomic absorption spectrometry. Analytica Chimica Acta 134, 283-291.

Tesson, M., 1973. Aspects Dynamiques de la Sédimentation dans la Baie de Marennes-Oléron. Université Bordeaux1, France p. 128.

Toth, J.R., Ingle, J.D., 1977. Determination of mercury in manganese nodules and crusts by cold-vapor atomic absorption spectrometry. Analytica Chimica Acta 92, 409-412.

Tueros, I., Borja, A., Larreta, J., Rodríguez, J.G., Valencia, V., Millàn, E., 2009. Integrating long-term water and sediment pollution data, in assessing chemical status within the European Water Framework Directive. Marine Pollution Bulletin 58, 1389-1400.

Valdès, J., Román, D., Guiñez, M., Rivera, L., Morales, T., Ávila, J., Cortés, P., 2009. Distribution and temporal variation of trace metal enrichment in surface sediments of San Jorge Bay, Chile. Environmental Monitoring and Assessment, $1-13$.

van Calsteren, PV.C. Thomas, L., 2006. Uranium-series dating applications in natural environmental science. Earth-Science Reviews 75, 155-175.

Zhang, J., Liu, C.L., 2002. Riverine composition and estuarine geochemistry of particulate metals in China-weathering features, anthropogenic impact and chemical fluxes. Estuarine, Coastal and Shelf Science 54, 1051-1070. 